\title{
Benefits, Difficulties and Conditions of Lesson Study Implementation in Basic Teacher Education: A Review
}

\author{
Eurydice-Maria D Kanellopoulou ${ }^{1} \&$ Maria Darra $^{1}$ \\ ${ }^{1}$ Department of Primary School Education, University of the Aegean, Rhodes, Greece \\ Correspondence: Eurydice-Maria D Kanellopoulou, Department of Primary School Education, University of the \\ Aegean, Rhodes, Greece
}

Received: March 9, 2019

Accepted: June 24, 2019

Online Published: June 28, 2019

doi:10.5430/ijhe.v8n4p18

URL: https://doi.org/10.5430/ijhe.v8n4p18

\begin{abstract}
The purpose of this study is to review the effectiveness of the implementation of the lesson study in higher education through the review of 28 empirical researches conducted both in Greece and the world over the past decade (2008-2018). In particular, the benefits, the difficulties and the conditions of effective implementation of the lesson study are examined. The lesson study is a method of improving teaching and learning for students and teachers. The results of the research revealed that the development of co-operation, reflection and professional development of preservice teachers are seen as important advantages due to the implementation of the lesson study. The preparation time, the tensions and the stress resulting from the monitoring of the teaching of their fellow students are mentioned as main difficulties, while participation and cooperation of preservice teachers and their support by trainers are seen as necessary conditions for its successful implementation. There is also a need for further research on the implementation of the lesson study in higher education, mainly in Greece, compared to the international field.
\end{abstract}

Keywords: lesson study, teacher professional development, higher education

\section{Introduction}

The continuous professional development of teachers, starting with their university education, is a prerequisite for upgrading the educational project. In order to achieve this goal, students' theoretical study programs should be modernized and implemented practically and effectively in the classrooms (Rekalidou, Karadimitriou \& Moumoulidou, 2014). Several researchers however, highlight the gap between curriculum theory and teaching (Juhler, 2018) and emphasize the importance of lifelong teacher education (Saito, 2012) to improve their theoretical and practical training.

Programs for a constructive approach can contribute to the effective professional development of future teachers, as constructivism is considered an appropriate framework for their education. Teachers find the positive impact on their pupils' perceptions and their own teaching skills, increasing their confidence and improving their teaching (Gordon \& Debus, 2002; Dejene, Bishaw \& Dagnew, 2018).

Several researchers also highlight the importance of co-operation between learners and between trainer and trainees, the value of interaction within the group, and the importance of reflection in their education (Rekalidou et al., 2014). With it, preservice teachers can collect information, process them within their group and use them appropriately in their teaching (Saito, 2012).

An effective program of professional development of future teachers, which is based on constructivism and can narrow the gap between theory and practice is a lesson study (Wessels, 2018; Rekalidou et al., 2014). The review of international and Greek literature shows that several studies have explored the contribution of the lesson study to improving student learning and professional development (McDowell, 2010; Levy \& Hourigan, 2016; Dania, Voutsina \& Moumouri, 2013) as well as to the formation of more positive attitudes and beliefs of participating preservice teachers (Carroll, 2013; Post \& Varoz, 2008; Juhler, 2018). In addition, several studies have studied the advantages of the lesson study, while fewer have dealt with the difficulties in implementing it (Hamzeh, 2014; Lucas, 2014; Burroughs \& Luebeck, 2010) and even fewer researches have explored the conditions for its effective implementation in higher education (Molina, 2012; McDowell, 2010).

The purpose of this study is to investigate the contribution of the lesson study to the preservice teachers by analyzing the relevant researches carried out during the last decade to draw useful conclusions, identify any gaps that may exist 
and make suggestions for further research.

\section{Lesson Study: Theoretical Approach}

The lesson study which was first implemented in Japan is a teaching method in which teachers, in a climate of cooperative and constructive dialogue, plan, teach, observe and evaluate the results of a lesson in a classroom (Espinosa, Datukan, Butron \& Tameta, 2018). With this teaching practice based on constructivism, dialogue between teachers is enhanced, participatory learning and educational reflection are supported. Improving teaching for the benefit of trainees and enhancing the professional development of teachers (Giannakidou, Gioftsali, Tzioras, 2013).

In order to carry out the lesson study, a team of teachers of the same specialty collaborates to design and teach a research lesson over a period of 10-15 hours in three to four weeks (Fernandez, 2002). It is distinguished in the following stages: a) setting goals, b) planning the research lesson, c) teaching, observing and data collecting of the research lesson, d) evaluation - feedback and re-teaching, and e) reflection, formulation and sharing final results (Stepanek, Appel, Leong, Mangan \& Mitchell, 2007).

In particular, teachers who teach the same subject in a school unit by expressing their views freely and through a fruitful and creative dialogue all co-create a common understanding of teaching the research lesson that a member of the group will carry out in the classroom (Lewis \& Hurd, 2011). For its planning, teachers analyze students' way of thinking and co-decide the most appropriate teaching methods and techniques. Also, at this stage, the teaching activities that students will perform are determined by the teachers, while estimating and commenting on their possible reactions and responses to each of them (Dania et al., 2013). The individual experiences and ideas of the participating teachers are tested in practice, are controlled and adopted, rejected or modified. This process motivates teachers to create a rich and well-structured lesson (Espinosa et al., 2018).

Teacher learning in the context of the lesson study results from the observation of the way the research lesson is taught by a group teacher, from the processing of data concerning the trainees' learning, which are collected during the course, as well as from the evaluation - feedback and reflection that contribute significantly to the improvement of the lesson itself as well as to the professional development of teachers (Stepanek et al., 2007). The results from the implementation of the research lesson are then communicated so that other teachers interested in the lesson study can get data and implement them (Murata \& Pothen, 2011).

The lesson study combines theoretical and practical learning and promotes high quality learning through high quality teaching. Improving the professional knowledge and skills of teachers enables them to be distinguished as teachers by providing high quality teaching to learners, giving the latter opportunities for meaningful acquisition of knowledge (Nishimura 2016; Wessels, 2018). Also, the lesson study enhances the critical thinking of learners through team and cooperative teaching, which activates their various skills and competences and improves their learning (Darling-Hammond \& Richardson, 2009).

The time required to complete all the stages of the lesson study and the lack of willingness to cooperate with teachers are the most important difficulties for its implementation (Lenski, Caskey \& Anfara, 2009). Also, another difficulty mentioned in implementing the lesson study is the lack of familiarity of teachers with other colleagues attending their teaching, which creates additional stress (Rekalidou, Moumoulidou, Karadimitriou, Mavrommatis, \& Salmont, 2013).

The prerequisites for the successful completion of the lesson study are the voluntary and equal participation of teachers and enhancement of collaborative culture among them, based on honest and two-way communication (Lewis, Perry \& Hurd, 2004).

\section{Purpose and Research Questions}

The purpose of the present study is to investigate the effectiveness of the lesson study on the continuous improvement of the basic education of preservice teachers in higher education, through the analysis of 29 researches from Greece and internationally which took place during the last decade (2008-2018). In particular, this study investigates: a. the benefits, b. the difficulties and c. the conditions of effective implementation of the lesson study in basic education of preservice teacher in higher education.

Indicative questions put to the investigation and which the research will attempt to answer are the following:

1st: Are there benefits from implementing the lesson study in basic education of preservice teacher in higher education?

2nd: Are there difficulties in implementing the lesson study in basic education of preservice teacher so as to influence their intention to use it? If so, which? 
3rd: What are the conditions and procedures for the effective implementation of the lesson study in basic education of preservice teacher?

\section{Method}

Research was conducted in accordance with the following criteria listed in Table 1.

Table 1. Selection criteria for investigations

\begin{tabular}{|c|c|}
\hline Selection criteria for invest & \\
\hline Research questions & $\begin{array}{l}\text { (a) Are there benefits from implementing the lesson study in basic } \\
\text { education of preservice teacher? }\end{array}$ \\
\hline & $\begin{array}{l}\text { (b) Are there difficulties in implementing the lesson study in basic } \\
\text { education of preservice teacher so as to influence their intention to } \\
\text { use it? If so, which? }\end{array}$ \\
\hline & $\begin{array}{l}\text { (c) What are the conditions and procedures for the effective } \\
\text { implementation of the lesson study in basic education of preservice } \\
\text { teacher? }\end{array}$ \\
\hline Geographical distribution & Universal \\
\hline Year of publication & $2008-2018$ \\
\hline Language & Greek, English \\
\hline Type of research & Empirical \\
\hline
\end{tabular}

Figure 1 shows the flow diagram of the methodology followed in this bibliographic review.

71 researches were found in the databases: google scholar, ERIC, Taylor \& Francis with the keyword: lesson study, teacher professional development.

6 researches were excluded because they were bibliographic reviews

Check titles and abstracts

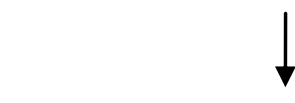

Check if they answer the research questions

37 researches were excluded

28 researches were included

Figure 1. Flow diagram of the methodology

\section{Results of the Research}

The results of the research contain data on the number of studies researched per year, their country of origin, the type and the size of the sample of surveys. Also, the results of this research are presented in tables per research question.

Figure 2 shows the number of researches per year. 


\section{The number of researches per year}

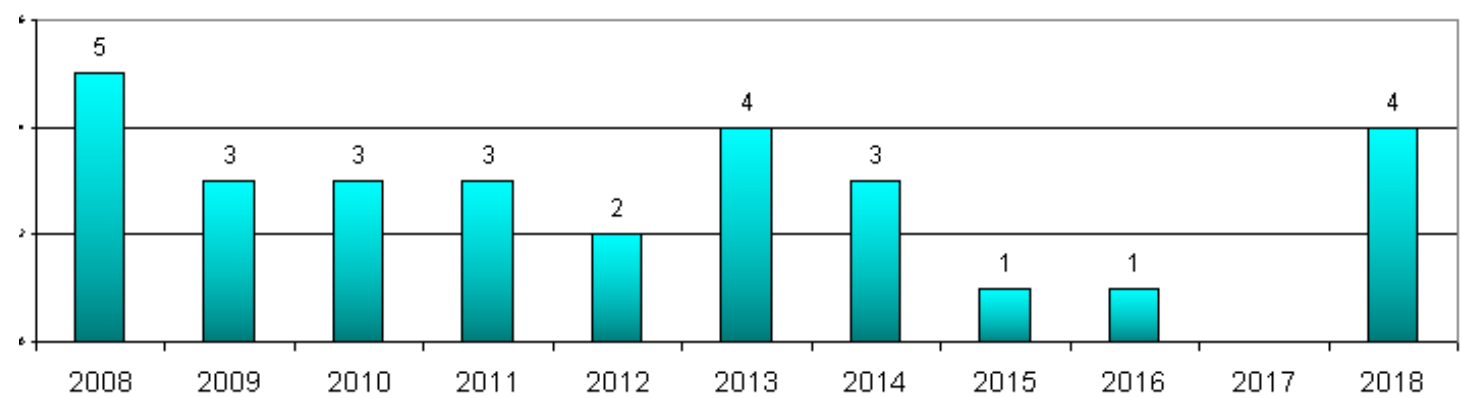

Figure 2. Number of researches per year

Figure 3 shows the number of researches in Greece and internationally.
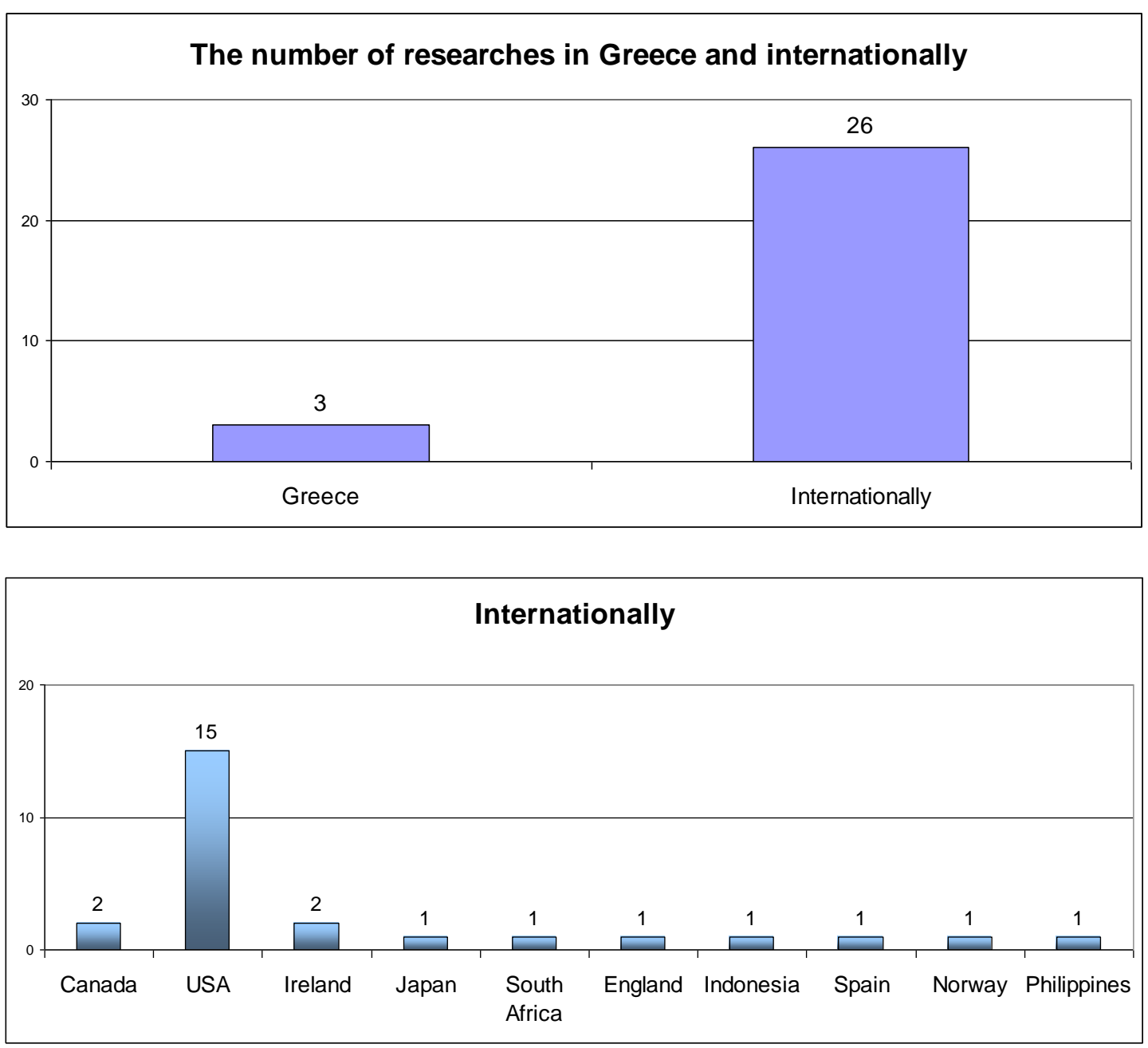

Figure 3. Number of researches in Greece and internationally

Figure 4 shows the number of researches per type. 


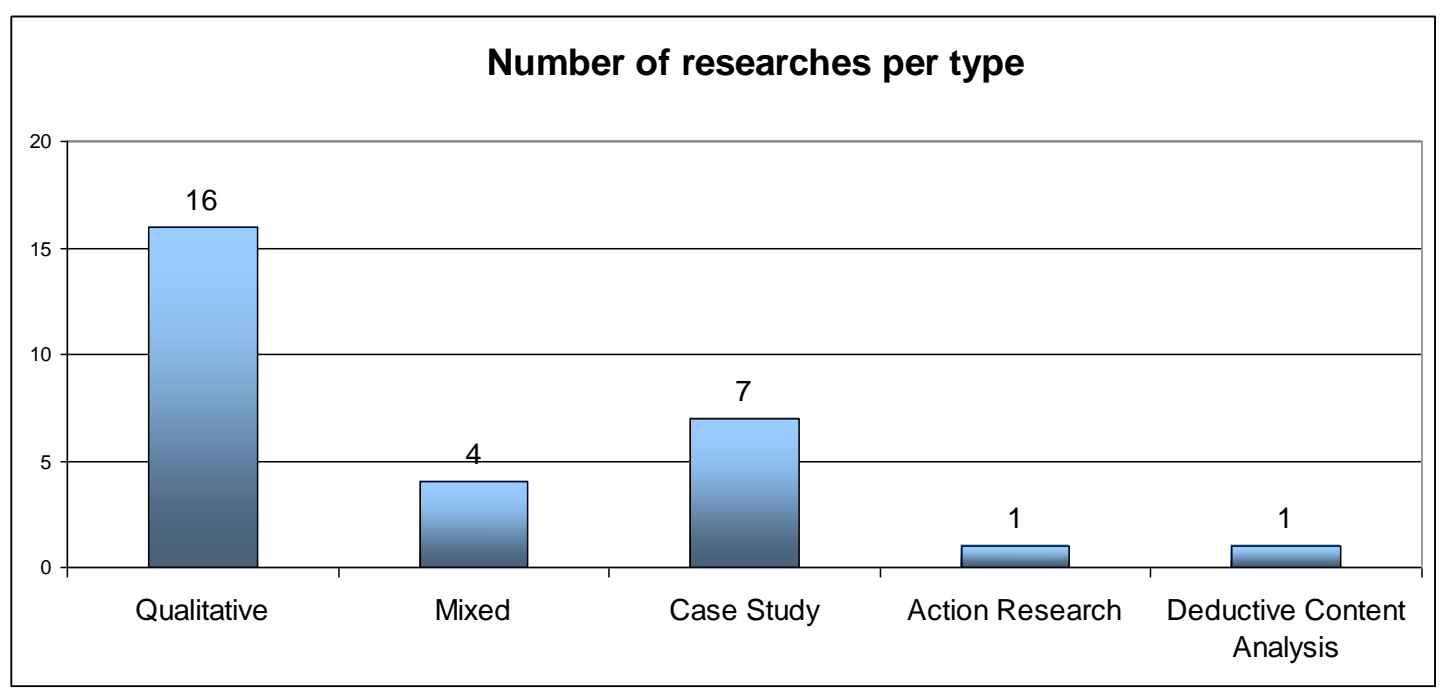

Figure 4. Number of researches per type

1st Research question: Are there benefits from implementing the lesson study in basic education of preservice teacher in higher education?

Table 2 summarizes the main findings of the researches examined regarding the benefits of implementing the lesson study in higher education.

Table 2. Benefits of implementing the lesson study in higher education

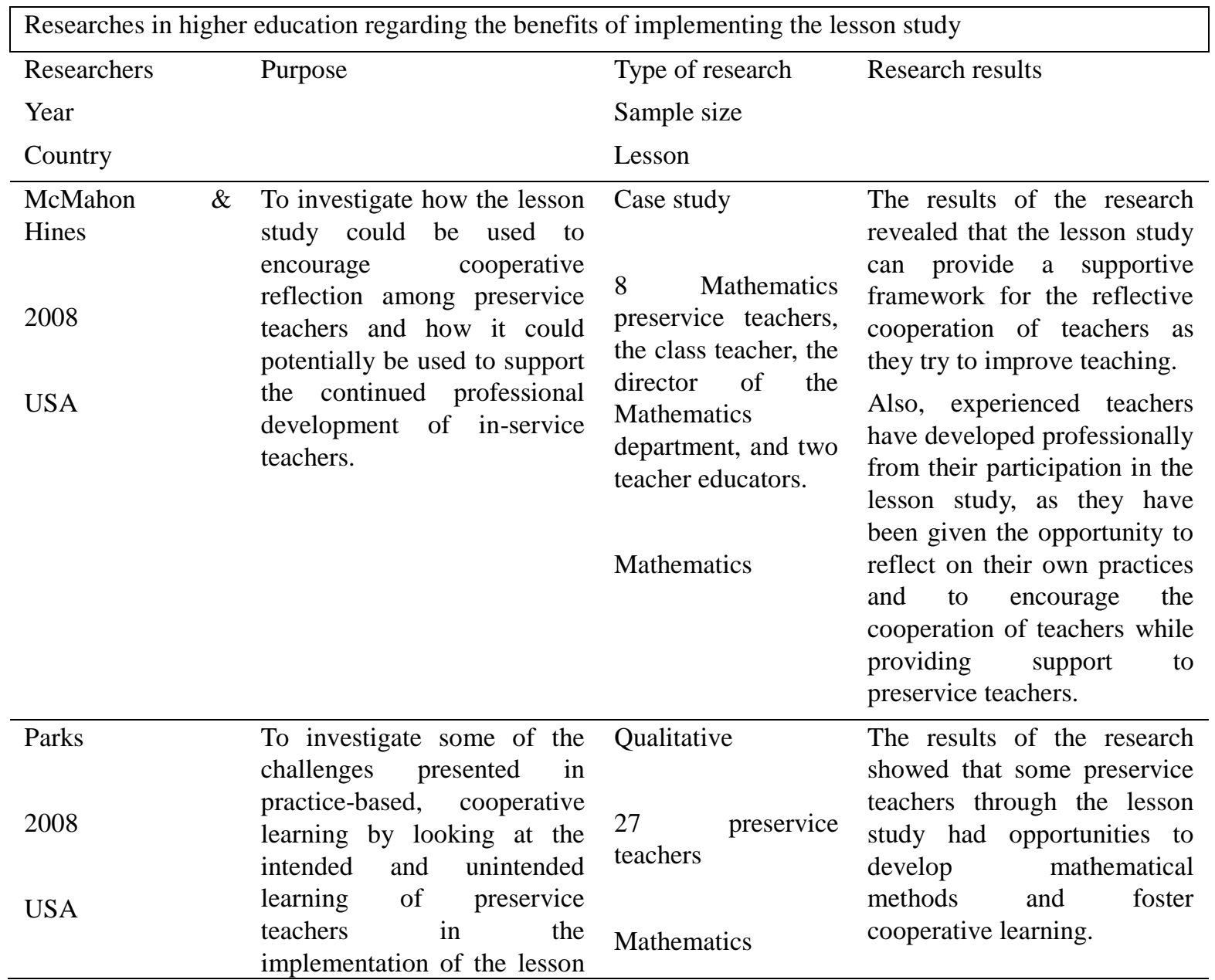




\begin{tabular}{|c|c|c|c|}
\hline & study in Mathematics. & & \\
\hline Post \& Varoz & $\begin{array}{l}\text { To investigate the cooperation } \\
\text { of preservice and inservice } \\
\text { teachers in lesson study } \\
\text { groups to learn about the } \\
\text { teaching of Mathematics } \\
\text { within the framework of } \\
\text { classroom practice. }\end{array}$ & $\begin{array}{l}3 \text { in-service teachers } \\
6 \quad \text { pre-service } \\
\text { teachers } \\
\text { Mathematics }\end{array}$ & $\begin{array}{l}\text { Collaboration in the group } \\
\text { was beneficial. }\end{array}$ \\
\hline $\begin{array}{l}\text { Saito, Hawe, } \\
\text { Hadiprawiroc \& } \\
\text { Empedhe } \\
2008\end{array}$ & $\begin{array}{l}\text { To investigate a case of } \\
\text { lesson study at the School of } \\
\text { Mathematics and Science of } \\
\text { the University of Yogyakarta } \\
\text { in Indonesia. More } \\
\text { specifically, it aims at } \\
\text { identifying and analyzing } \\
\text { existing issues and problems } \\
\text { in order to promote the lesson } \\
\text { study as a method of } \\
\text { improving the quality of } \\
\text { education of preservice } \\
\text { teachers of faculties at the } \\
\text { Universities of Indonesia. }\end{array}$ & $\begin{array}{l}\text { Case study } \\
8 \text { students } \\
8 \text { members of } \\
\text { Teaching Research } \\
\text { Staff }\end{array}$ & $\begin{array}{l}\text { The most important point in } \\
\text { the lesson study is the } \\
\text { reflection on the learning of } \\
\text { students. }\end{array}$ \\
\hline Sims \& Walsh & $\begin{array}{l}\text { To investigate whether first } \\
\text { year and second year } \\
\text { preservice teachers can } \\
\text { analyze their lessons based on } \\
\text { lesson goals, conduct detailed } \\
\text { discussions on educational } \\
\text { strategies, such as question } \\
\text { techniques, predicting student } \\
\text { responses, and how lesson } \\
\text { flow affects the students' } \\
\text { understanding, and to judge } \\
\text { the lesson plan and not the } \\
\text { teacher by implementing the } \\
\text { lesson study. Also, another } \\
\text { goal added in the second year } \\
\text { focused on developing the } \\
\text { ability of preservice teachers } \\
\text { to observe and collect real } \\
\text { learning data. }\end{array}$ & $\begin{array}{l}\text { Qualitative } \\
\text { 1st year: } 32 \\
\text { preservice } \\
\text { teachers of } \\
\text { preschool education } \\
\text { 2nd year: } 25 \\
\text { pre-school teachers } \\
\text { preservice } \\
\text { teachers of } \\
\text { preschool education }\end{array}$ & $\begin{array}{l}\text { The results of the research } \\
\text { revealed that the second year's } \\
\text { preservice teachers worked } \\
\text { perfectly with their } \\
\text { colleagues. } \\
\text { The feedback session was a } \\
\text { learning opportunity for } \\
\text { second year preservice } \\
\text { teachers. }\end{array}$ \\
\hline $\begin{array}{l}\text { Chassels } \\
\text { Melville }\end{array}$ & $\begin{array}{l}\text { To investigate the benefits } \\
\text { and challenges } r \text { of } \\
\text { participating teacher } \\
\text { candidates in the lesson study. }\end{array}$ & $\begin{array}{l}60 \\
\text { candidates } \\
20 \\
\text { field practicum asso } \\
\text { ciate teachers } \\
\text { the pre - }\end{array}$ & $\begin{array}{l}\text { The findings show that the } \\
\text { lesson study provides } \\
\text { opportunities for teacher } \\
\text { candidates to create } \\
\text { professional learning } \\
\text { communities, to deepen the } \\
\text { understanding of the } \\
\text { curriculum and pedagogy, and } \\
\text { to develop critical } \\
\text { observation, analysis and }\end{array}$ \\
\hline
\end{tabular}




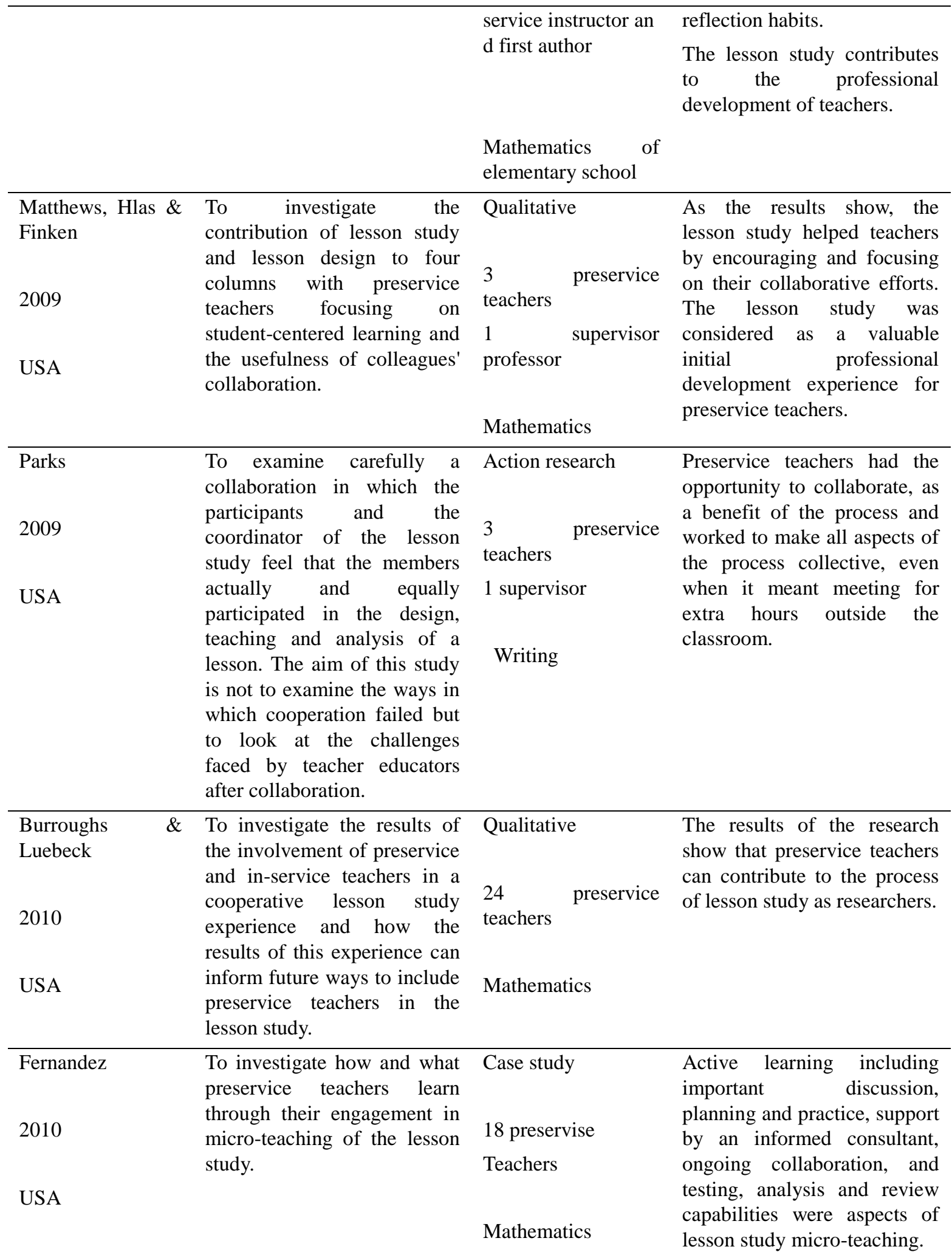




\begin{tabular}{|c|c|c|c|}
\hline McDowell & $\begin{array}{l}\text { To investigate the experiences } \\
\text { experienced by preservice } \\
\text { teachers in a lesson study } \\
\text { centered on teaching and } \\
\text { learning the nature of } \\
\text { Science }\end{array}$ & $\begin{array}{l}6 \\
\text { teachers }\end{array}$ & $\begin{array}{l}\text { Students who worked at } \\
\text { higher levels of reflection } \\
\text { deepened more in the } \\
\text { pedagogical content of } \\
\text { knowledge. }\end{array}$ \\
\hline USA & & Science & \\
\hline Carrier & $\begin{array}{l}\text { To examine the views of } \\
\text { preservice teachers by } \\
\text { implementing the lesson } \\
\text { study in their initial efforts to } \\
\text { design and teach a lesson of } \\
\text { scientific research on their } \\
\text { peers and to encourage } \\
\text { teacher educators to review } \\
\text { some of these long } \\
\text { established, research-based } \\
\text { teaching strategies with } \\
\text { preservice teachers. An }\end{array}$ & $\begin{array}{l}57 \\
\text { teachers }\end{array}$ & $\begin{array}{l}\text { Advantages: Cooperation, the } \\
\text { value of observation and } \\
\text { reflection in understanding } \\
\text { their teaching and the benefits } \\
\text { of revising their lessons. } \\
\text { Preservice teachers have } \\
\text { recognized that lessons are } \\
\text { improved by observation and } \\
\text { feedback, and these } \\
\text { experiences can help them } \\
\text { begin to accept and learn } \\
\text { from constructive criticisms. }\end{array}$ \\
\hline
\end{tabular}

school policy makers to look at the effectiveness of these change-promoting strategies and policies, including providing time for teachers to collaborate.

\begin{tabular}{ll}
\hline Elipane & To investigate how some \\
elements of the lesson study \\
2011 & are used as a powerful \\
& intervention to facilitate the \\
& familiarization of future \\
Japan & teachers of Mathematics with \\
& the actual teaching practice in \\
& schools during the student's \\
& teaching program.
\end{tabular}

Qualitative

(n)

(1)

7 preservice

teachers

3 inservice teachers

2 University

professors

Mathematics
The results of the research revealed that four issues related to the skills, abilities and habits of the mind were more intense in research: first, the understanding of the resources needed for classroom teaching, secondly the use of school and class as venues research, thirdly the involvement in major reflections, and fourth the forging of the spirit of cooperation. Also, the lesson study can improve the training of preservice teachers.

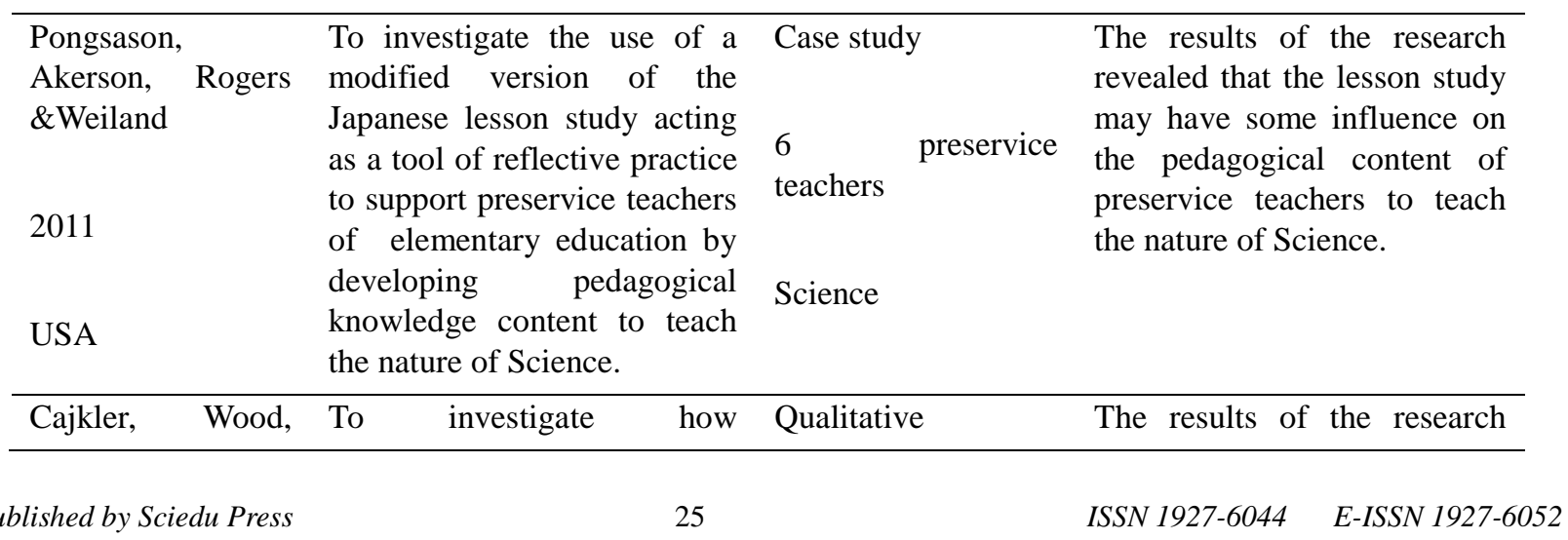




\begin{tabular}{|c|c|c|c|}
\hline Norton \& Pedder & $\begin{array}{l}\text { participation in the lesson } \\
\text { study contributed to } \\
\text { collaborative learning for } \\
\text { both trainees and mentors. }\end{array}$ & $\begin{array}{l}2 \text { preservice } \\
\text { teachers, } \\
2 \text { consultants, } \\
1 \text { newly appointed } \\
\text { teacher } \\
1 \text { experienced } \\
\text { teacher } \\
\text { Geography, Modern } \\
\text { Languages }\end{array}$ & $\begin{array}{l}\text { revealed that the lesson study } \\
\text { facilitated the rapid } \\
\text { integration of the future } \\
\text { teacher into departmental } \\
\text { work practices, according to } \\
\text { the mentors, while the } \\
\text { preservice teachers claimed to } \\
\text { have benefited from the group } \\
\text { approach of the lesson study. } \\
\text { With successful completion, } \\
\text { the lesson study improves the } \\
\text { professional development of } \\
\text { teachers. }\end{array}$ \\
\hline $\begin{array}{l}\text { Giannakidou, } \\
\text { Gioftsali } \\
\text { Tzioras } \\
2013\end{array}$ & $\begin{array}{l}\text { To investigate and interpret } \\
\text { the reflective act developed } \\
\text { by the students of the } \\
\text { Department of Education } \\
\text { Sciences in Pre-school Age of } \\
\text { Democritus University during } \\
\text { their teaching practice, } \\
\text { implementing an adapted } \\
\text { version of the lesson study in } \\
\text { conjunction with an open } \\
\text { student-centered approach, } \\
\text { such as the Project method. }\end{array}$ & $\begin{array}{l}\text { Case study } \\
2 \text { groups of } 8 \\
\text { students } \\
1 \text { supervisor }\end{array}$ & $\begin{array}{l}\text { The results of the research } \\
\text { revealed that students also } \\
\text { showed samples of } \\
\text { technocratic and interpretative } \\
\text { reflection before and after the } \\
\text { act. At the same time, } \\
\text { students critical reflection } \\
\text { was developed, only in } \\
\text { individual exhibitions } \\
\text { submitted after the } \\
\text { completion of their classroom } \\
\text { practice. } \\
\text { One factor that favored the } \\
\text { development of reflective } \\
\text { thinking of sample students } \\
\text { was the cooperative character } \\
\text { of the model and the process } \\
\text { of collective feedback. }\end{array}$ \\
\hline $\begin{array}{l}\text { Dania, Voutsina \& } \\
\text { Moumouri }\end{array}$ & $\begin{array}{l}\text { To present the model of the } \\
\text { lesson study, as implemented } \\
\text { to the practice of third-year } \\
\text { students of the Department of } \\
\text { Physical Education and Sport } \\
\text { Science, National and } \\
\text { Kapodistrian University of } \\
\text { Athens. The main aim was to } \\
\text { highlight the unseen aspects } \\
\text { of physics lessons teaching } \\
\text { and through it the } \\
\text { identification of the elements } \\
\text { that influence } \\
\text { identification of an effective } \\
\text { lesson. }\end{array}$ & Physical Education & $\begin{array}{l}\text { The detailed analysis of the } \\
\text { lesson and its multiple } \\
\text { opportunities for } \\
\text { collaboration, focused } \\
\text { feedback and reflection } \\
\text { contributed to linking theory } \\
\text { to practice, creatively } \\
\text { promoting both their personal } \\
\text { and professional } \\
\text { development. }\end{array}$ \\
\hline Hamzeh & $\begin{array}{l}\text { To investigate whether the } \\
\text { lesson study enables } \\
\text { preservice teachers to } \\
\text { improve their teaching } \\
\text { through exploratory learning. } \\
\text { Also, if teachers' beliefs }\end{array}$ & 48 participants & $\begin{array}{l}\text { Cooperation and professional } \\
\text { development of teachers. }\end{array}$ \\
\hline
\end{tabular}




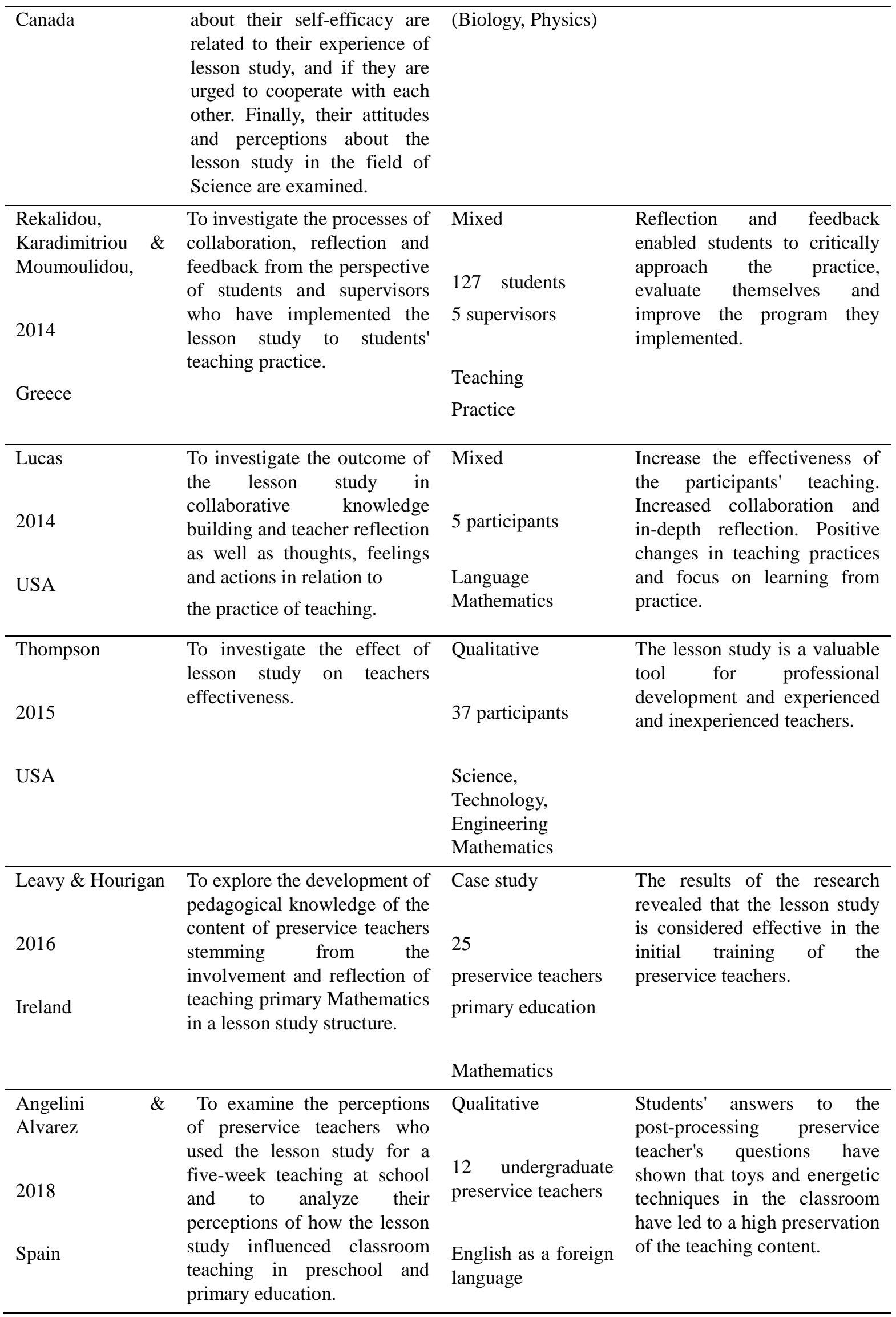




\begin{tabular}{|c|c|c|c|}
\hline Juhler & $\begin{array}{l}\text { The study investigates the } \\
\text { problem of the difference } \\
\text { between theory and practice } \\
\text { by introducing the lesson } \\
\text { study and the representation }\end{array}$ & $\begin{array}{l}\text { Deductive content } \\
\text { analysis }\end{array}$ & $\begin{array}{l}\text { During the intervention, the } \\
\text { preservice teachers focused } \\
\text { more on the goals of teaching, } \\
\text { students and their learning, on } \\
\text { the better representation of }\end{array}$ \\
\hline Norway & $\begin{array}{l}\text { of content as an intervention } \\
\text { in the practical training of } \\
\text { teachers. }\end{array}$ & $\begin{array}{l}7 \quad \text { preservice } \\
\text { teachers } \\
2 \text { mentors }\end{array}$ & $\begin{array}{l}\text { specific content and on the } \\
\text { specific assessment compared } \\
\text { to the current state of the } \\
\text { practice. }\end{array}$ \\
\hline
\end{tabular}

Physics

2nd Research question: Are there difficulties in implementing the lesson study in basic education of preservice teachers so as to influence their intention to use it? If so, which?

Table 3 summarizes the main findings of the researches examined regarding the difficulties in implementing the lesson study in higher education.

Table 3. Difficulties in implementing the lesson study in higher education.

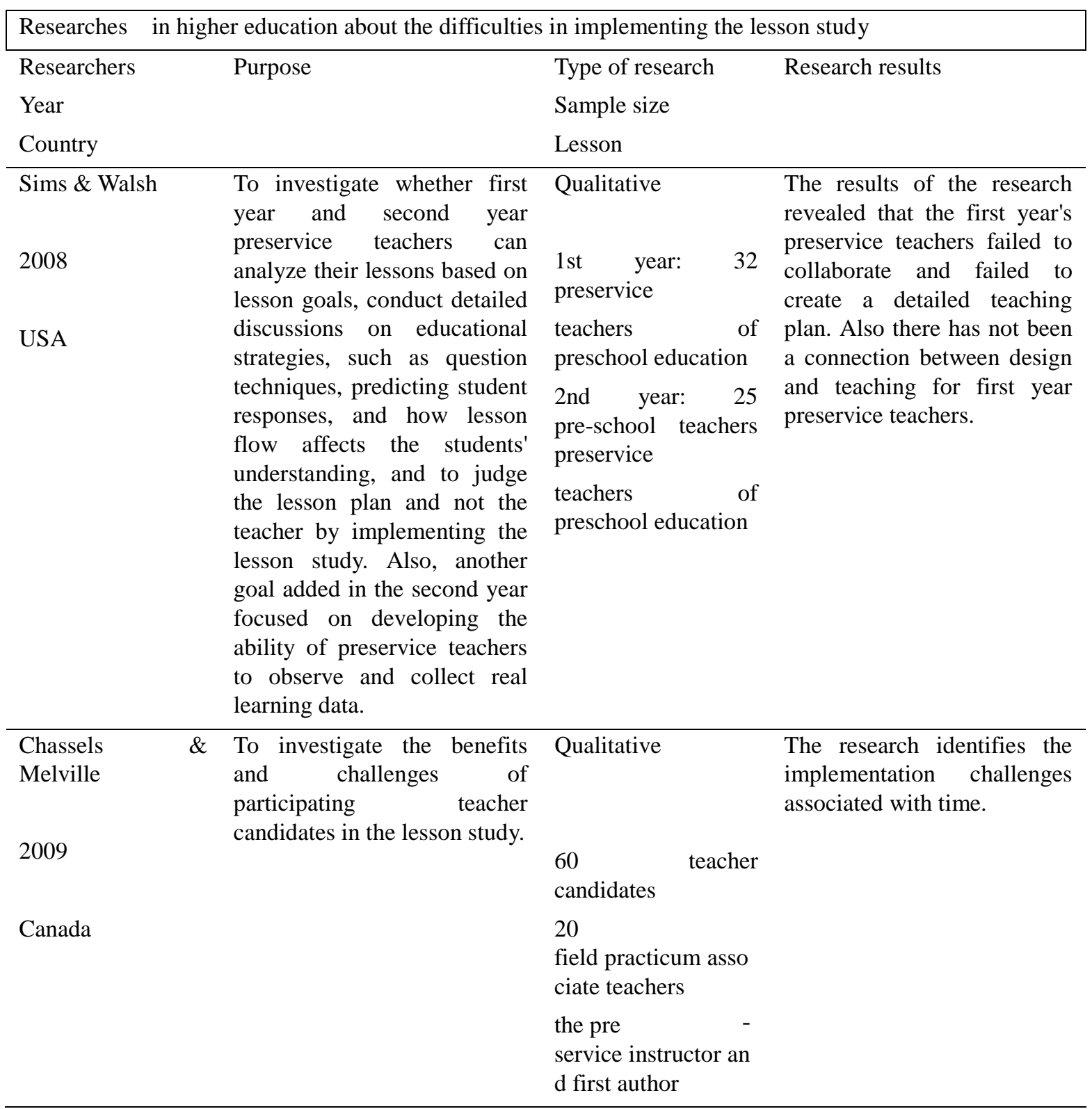




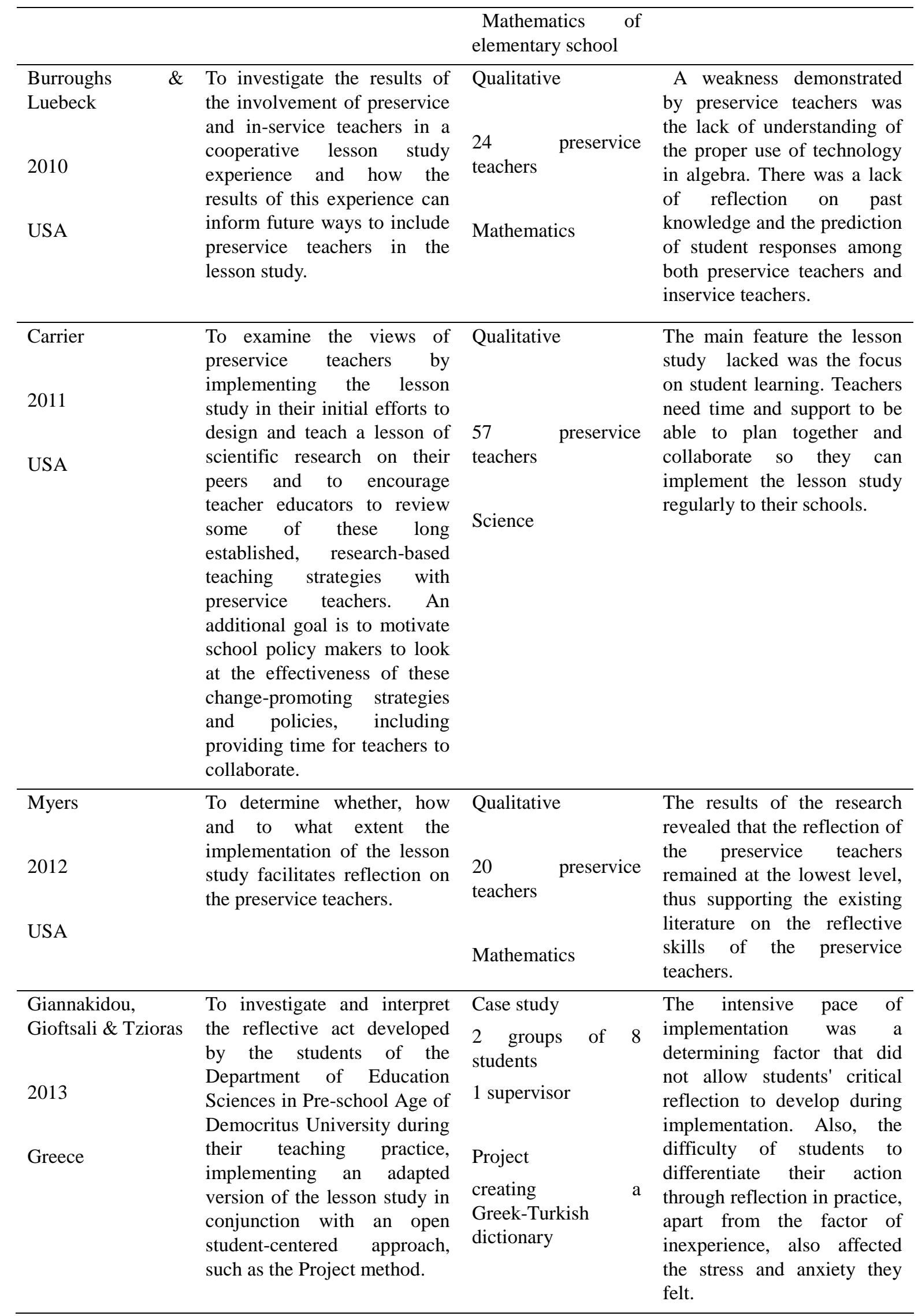




\begin{tabular}{|c|c|c|c|}
\hline $\begin{array}{l}\text { Rekalidou, } \\
\text { Karadimitriou \& } \\
\text { Moumoulidou, }\end{array}$ & $\begin{array}{l}\text { To investigate the processes } \\
\text { of collaboration, reflection } \\
\text { and feedback from the } \\
\text { perspective of students and } \\
\text { supervisors who have } \\
\text { implemented the lesson study } \\
\text { to students' teaching practice. }\end{array}$ & $\begin{array}{l}127 \text { students } \\
5 \text { supervisors }\end{array}$ & $\begin{array}{l}\text { In some groups there have } \\
\text { been cooperative difficulties } \\
\text { and tensions for mitigating } \\
\text { which required time to spend. } \\
\text { Sometimes the students' } \\
\text { fatigue and their attempt to } \\
\text { respond to the program } \\
\text { requirements were the causes } \\
\text { of tension. }\end{array}$ \\
\hline $\begin{array}{l}\text { Espinoza, } \\
\text { Datukan, Burton \& } \\
\text { Tameta }\end{array}$ & $\begin{array}{l}\text { To investigate preservice } \\
\text { teachers' perceptions of using } \\
\text { the lesson study as a } \\
\text { framework for teaching High } \\
\text { School Chemistry. In } \\
\text { particular, this study } \\
\text { investigates } \\
\text { Chemistry preservice teachers } \\
\text { believe that this framework } \\
\text { will help improve academic } \\
\text { achievements in Chemistry } \\
\text { compared to traditional } \\
\text { teaching as well as the } \\
\text { advantages and disadvantages } \\
\text { of this framework. Finally, if } \\
\text { they suggest that this } \\
\text { framework will be used in } \\
\text { primary schools. }\end{array}$ & $\begin{array}{l}30 \text { young Chemistry } \\
\text { preservice teachers }\end{array}$ & $\begin{array}{l}\text { The results of the study } \\
\text { showed that although most of } \\
\text { the participants agreed to use } \\
\text { the framework, most of them } \\
\text { failed to understand the basic } \\
\text { process of the productive } \\
\text { lesson study. The drawbacks } \\
\text { include the time element. }\end{array}$ \\
\hline
\end{tabular}

3rd Research question: What are the conditions and procedures for the effective implementation of the lesson study in basic education of preservice teacher?

Table 4 summarizes the main findings of the researches examined regarding the conditions and procedures for the effective implementation of the lesson study in higher education.

Table 4. Conditions and procedures for the effective implementation of the lesson study in higher education

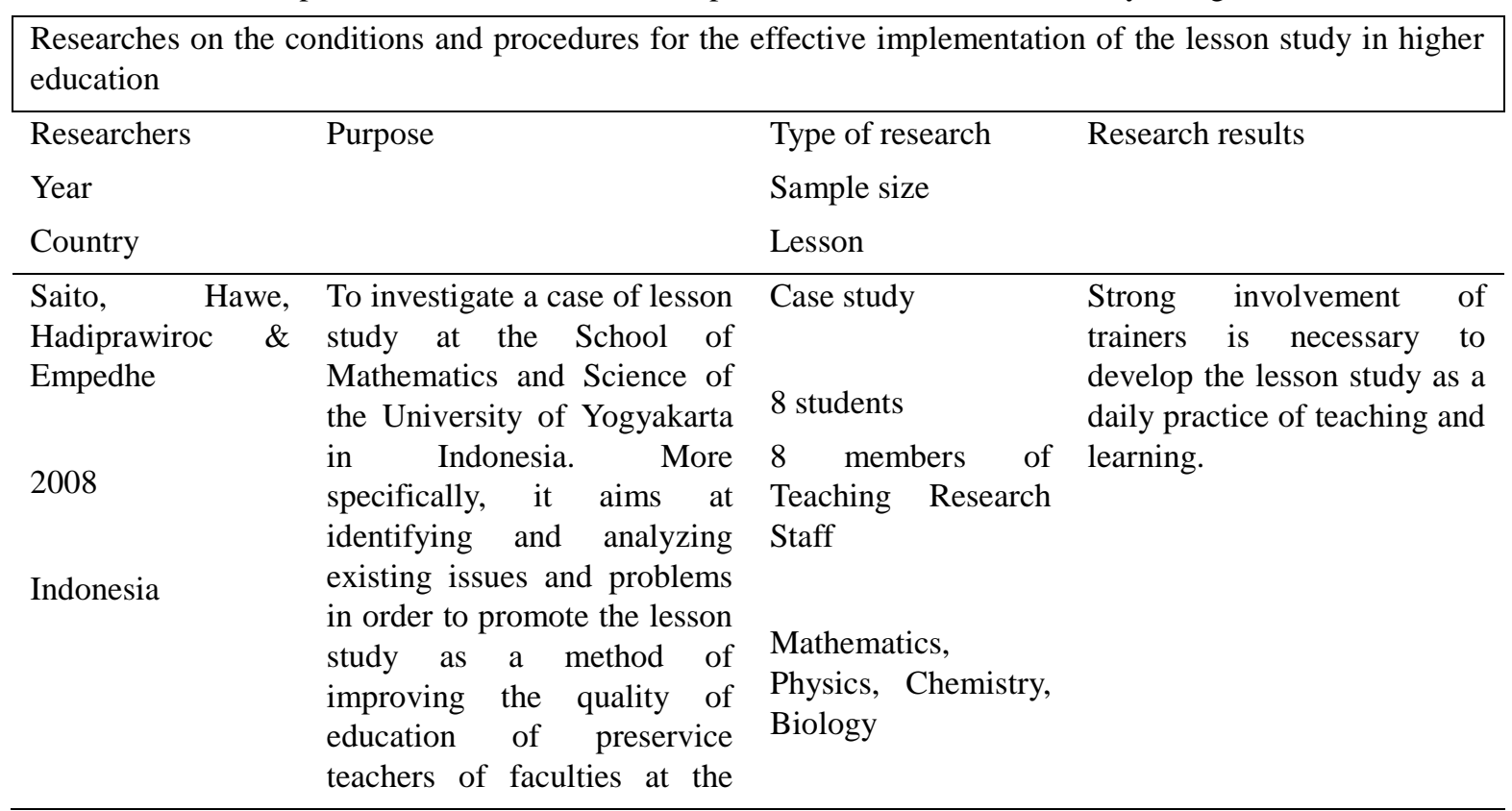




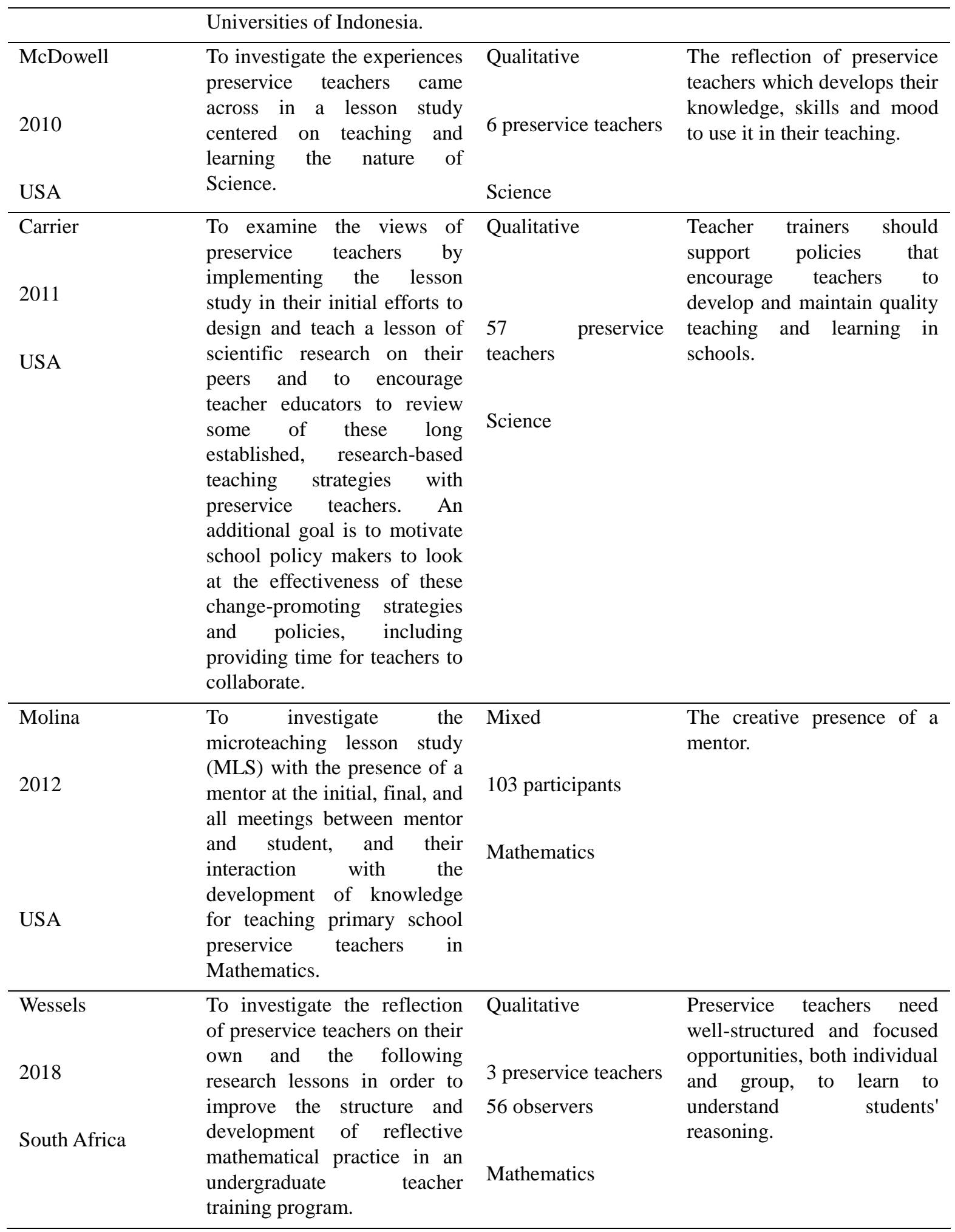

\section{Discussion of Research Results}

Overall, the average of surveys per year from 2008 to 2018 is 2.8. Most researches have been conducted internationally and the largest number has been conducted in the US $(n=15)$, while fewer in other countries. In Greece, a minimum number of surveys $(n=3)$ compared with the international area $(n=25)$ has been identified.

Regarding the benefits of implementing the lesson study in higher education, several international studies have been examined in Mathematics (McMahon \& Hines, 2008; Parks, 2008; Post \& Varoz, 2008; Saito, Hawe, Hadiprawiroc 
\& Empedhe, 2008; Chassels \& Melville, 2009; Matthews, Hlas \& Finken, 2009; Burroughs \& Luebeck, 2010; Fernandez, 2010; Elipane, 2011; Lucas, 2014; Thompson, 2015; Leavy \& Hourigan, 2016), Physics (Saito et al., 2008; Hamzeh, 2014; Juhler, 2018), Chemistry (Saito et al., 2008), Biology (Saito et al., 2008; Hamzeh, 2014),Writing (Parks, 2009), Science (McDowell, 2010; Carrier, 2011; Pongsason, Akerson, Rogers \& Weiland, 2011; Thompson, 2015), Geography and Modern Languages (Cajkler, Wood, Norton and Pedder, 2013), Technology (Thompson, 2015), Engineering (Thompson, 2015), English as a foreign language (Angelini \& Alvarez, 2018) and Language Courses (Lucas, 2014). In Greece, a smaller number of researches was found, examining the benefits of implementing the lesson study in higher education in Teaching Practice (Rekalidou et al., 2014), the Project method (Giannakidou et al., 2013) and Physical Education (Dania et al., 2013). The most important benefits of implementing the lesson study are co-operation, professional development of preservice teachers, reflection, active learning including important discussion, planning, practice, observation and feedback. These findings are confirmed by other researchers (Stepanek et al., 2007).

Regarding the difficulties in implementing the lesson study in higher education, a small number of international researches have been examined in Mathematics (Chassels \& Melville, 2009; Burroughs \& Luebeck, 2010; Myers, 2012), Science (Carrier, 2011) and Chemistry (Espinoza et al., 2018), while a much smaller number of researches were found in Greece in Teaching Practice (Rekalidou et al., 2014) and the Project method (Giannakidou et al., 2013). The most important difficulties in the implementation of the lesson study by the preservice teachers are the difficulty of cooperation, the pressure of time, tensions, the inability to predict student responses, the lack of focus on student learning, the lack of understanding of the proper use of technology, the inexperience, stress and anxiety resulting from the observation of the teaching, the reflection, the fatigue due to their attempt to respond to the requirements of the particular method. These findings are in agreement with the results of other researchers (Lenski et al., 2009; Rekalidou et al., 2013).

Regarding the conditions and procedures for the effective implementation of the lesson study in higher education, only five international studies have been examined in Mathematics (Saito et al., 2008; Molina, 2012; Wessels, 2018), Physics (Saito et al., 2008), Chemistry (Saito et al., 2008), Biology (Saito et al., 2008) and Science (McDowell, 2010; Carrier, 2011) and none in Greece. The most important prerequisites for the effective implementation of the lesson study are the reflection of the preservice teachers who develop their knowledge, skills and willingness to use it in their teaching, the participation and cooperation of teachers, the creative presence of the mentor, policy support from teacher educators who encourage teachers to develop and maintain quality teaching. These findings are also recorded in other studies (Stepanek et al., 2007).

\section{Conclusions}

From the review of the last decade researches studied, results an average 2.8 per year with most of them being conducted in the US, while few in Greece.

In particular, regarding the benefits resulting from the implementation of the lesson study in higher education, most researches have been identified in the international field, mainly in Mathematics but also in other subjects such as Physics, Chemistry, Biology, Science, Writing, Geography, Modern Languages, Technology, Mechanical, English and Language courses. In Greece, a smaller number of studies were found in Teaching Practice, Project method and Physical Education. Consequently, the exploration of the benefits of the lesson study demonstrates the need for further research, especially in Greece.

The most important benefits of implementing the lesson study are co-operation, professional development of preservice teachers, reflection, active learning including constructive discussion, planning, practice, observation and feedback.

Regarding the difficulties resulting from the implementation of the lesson study in higher education, a small number of international studies were found in Mathematics, Science and Chemistry, while in Greece a much smaller number of researches were studied, in Teaching Practice and in the Project method. As a consequence, there is a need for further research, both in the international and the Greek field so as to explore the difficulties in implementing the lesson study.

The most important difficulties in the implementation of the lesson study by the preservice teachers are the difficulty of co-operation, time pressure, tensions, failure to predict student responses, lack of focus on student learning, inadequate understanding of proper use of technology, the inexperience, stress and anxiety resulting from the observation of the teaching, the reflection, the fatigue due to their attempt to respond to the requirements of the particular method. 
Regarding the conditions and procedures for the effective implementation of the lesson study in higher education, only five international studies in Mathematics, Physics, Chemistry, Biology and Science were identified and no research was identified in Greece. Therefore, more research is needed in Greece and internationally.

The most important prerequisites for the effective implementation of the lesson study are the reflection of the preservice teachers who develop their knowledge, skills and willingness to use it in their teaching, the participation and cooperation of teachers, the creative presence of the mentor and policy support from teacher educators who encourage teachers to develop and maintain quality teaching.

\section{Restrictions}

The constraints of this research include the small number of studies under consideration, the search for specific databases, and the focus on specific subjects of the lesson study in higher education.

\section{Suggestions}

Suggestions for further research could be the theoretical and practical exploration of other subjects related to the lesson study, such as the needs of teachers for training on its implementation. Moreover, by conducting comparative researches at different levels of education in the educational system of Greece on the results of its implementation and its impact on learners and educators, valuable conclusions will be drawn on the mobilization and improvement of trainees' performance, on the attitudes and beliefs of trainees and educators, as well as on the benefits, the difficulties and the conditions for effective implementation of the lesson study.

\section{References}

Angelini, M., \& Álvarez, N. (2018). Spreading lesson study in pre-service teacher instruction. International Journal for Lesson and Learning Studies, 7(1), 23-36. https://doi.org/10.1108/IJLLS-03-2017-0016

Burroughs E., \& Luebeck J. (2010). Pre-service Teachers in Mathematics Lesson Study. Montana State University. The Mathematics Enthusiast, 7(2).

Cajkler, W., Wood, P., Norton, J., \& Pedder, D. (2013). Lesson Study: towards a collaborative approach to learning in Initial Teacher Education? Cambridge Journal of Education, 43(4), 537-554, https://doi.org/10.1080/0305764X.2013.834037

Carrier, S. (2011). Implementing and Integrating Effective Teaching Strategies Including Features of Lesson Study in an Elementary Science Methods Course. The Teacher Educator, 46(2), 145-160. https://doi.org/10.1080/08878730.2011.552666

Chassels, C., \& Melville, W. (2009). Collaborative, Reflective and Iterative Japanese Lesson Study in an Initial Teacher Education Program: Benefits and Challenges. Canadian Journal of Education, 32(4), 734-763.

Dania, A., Voutsina, I., \& Moumouri, A. (2013). The application of the Lesson Study model on the teaching practice of physical education university students. Proccedings of the International Scientific Conference eRA-8, Athens, Greece. https://doi.org/10.25236/eduer.2017.062

Darling-Hammond, L., \& Richardson, N. (2009). Teacher learning: What matters? Educational Leadership, 66(5), 46-53.

Dejene, W., Bishaw, A., \& Dagnew, A. (2018). Preservice teachers' approaches to learning and their teaching approach preferences: Secondary teacher education program in focus. Cogent Education, 5, 1502396. https://doi.org/10.1080/2331186X.2018.1502396

Elipane, L. (2011). Incorporating lesson study in pre-service mathematics teacher education. In xxxx (Eds.). Proceedings of the 35th Conference of the International Group for the Psychology of Mathematics Education, 1, xxx-yyy. Ankara, Turkey: PME.

Espinosa, A., Datukan, J., Butron, B., \& Tameta, A. (2018). Perceptions of pre-service chemistry teachers on the utilization of productive lesson study as a framework for teaching and learning. International Journal for the Scholarship of Teaching and Learning, 12(1). https://doi.org/10.20429/ijsotl.2018.120109

Fernandez, C. (2002). Learning from Japanese approaches to professional development: the case of lesson study. Journal of Teachers Education, 53(5), 393-405. https://doi.org/10.1177/002248702237394

Fernandez, M. (2010). Investigating how and what prospective teachers learn through microteaching lesson study. Teaching and Teacher Education, 26, 351-362. https://doi.org/10.1016/j.tate.2009.09.012

Giannakidou, E., Gioftsali, K., \& Tzioras, E. (2013). The reflective action of prospective teachers when 
implementing an appied version of the Lesson Study model. Hellenic Journal of Research in Education, 1, 30-58. Available at: https://ejournals.epublishing.ekt.gr/index.php/hjre/article/view/8791/9012

Gordon, C., \& Debus, R. (2002). Developing deep learning approaches and personal teaching efficacy within a preservice teacher education context. British Journal of Educational Psychology, 72, 483-511. https://doi.org/10.1348/00070990260377488

Hamzeh, F. (2014). Lesson Study-Building Communities of Learning Among Pre-Service Science Teachers. Electronic Theses and Dissertations. 5114. https://scholar.uwindsor.ca/etd/5114.

Juhler, M. (2018). Pre-service teachers' reflections on teaching a physics lesson: How does Lesson Study and Content Representation affect pre-service teachers' potential to start developing PCK during reflections on a physics lesson. NORDINA, 14(1), 22-36. https://doi.org/10.5617/nordina.2433

Leavy, A., \& Hourigan, M. (2016). Using lesson study to support knowledge development in initial teacher education: Insights from early number classrooms. Teaching and Teacher Education, 57, 161-175. https://doi.org/10.1016/j.tate.2016.04.002

Lenski, S., Caskey, M., \& Anfara, V. (2009). Using the Lesson Study Approach to Plan for Student Learning. Middle School Journal, 40(3), 50-57. https://doi.org/10.1080/00940771.2009.11495587

Lewis, C., \& Hurd, J. (2011). Lesson Study step by step. How Teacher Learning Communities Improve Instruction. Portsmouth, NH, USA.

Lewis, C., Perry, R., \& Hurd, J. (2004). A deeper look at lesson study. Educational Leadership, 61(5), 18-23.

Lucas, M. (2014). Lesson Study, a Means for Fostering Collaborative Reflection: $\quad$ Effects on the Self-Efficacy and Teaching Practices of Developmental Education College Success Course Instructors. Dissertation, Arizona State University.

Matthews, M., Hlas, C., \& Finken, T. (2009). Using Lesson Study and Four-Column Lesson Planning with Preservice Teachers. Mathematics Teacher, 102(7), 504- 508.

McDowell, A. (2010). Preservice Teachers' Use of Lesson Study in Teaching Nature of Science. Dissertation, Georgia State University. http://scholarworks.gsu.edu/msit_diss/65

McMahon, M., \& Hines, E. (2008). Lesson Study with Preservice Teachers. Mathematics Teacher, 102(3), 186-191.

Molina, R. (2012). Microteaching Lesson Study: Mentor Interaction Structure and its Relation to Elementary Preservice Mathematics Teacher Knowledge Development. FIU Electronic Theses and Dissertations. 616. https://doi.org/10.25148/etd.FI12050222

Myers, J. (2012). Lesson Study as a Means for Facilitating Preservice Teacher Reflectivity. International Journal for the Scholarship of Teaching and Learning, 6(1). https://doi.org/10.20429/ijsotl.2012.060115

Nishimura, K. (2016). Lesson study at the upper secondary level in Japan. In Presentation, Lesson Study Mini Conference. Nottingham, UK.

Parks, A. (2008). Messy learning: Preservice teachers' lesson study conversations about mathematics and students. Teaching and Teacher Education, 24(5), 1200-1216. https://doi.org/10.1016/j.tate.2007.04.003

Parks, A. (2009). Collaborating about What? An Instructor's Look at Preservice Lesson Study. Teacher Education Quarterly, 36(4), 81-97.

Pongsanon, K., Akerson, V., Rogers, M., \& Weiland, I. (2011). Exploring the Use of Lesson Study to Develop Elementary Preservice Teachers' Pedagogical Content Knowledge for Teaching Nature of Science. Paper presented at the National Association for Research in Science Teaching. Orlando, Florida. https://doi.org/10.1007/s10763-015-9690-x

Post, G., \& Varoz, S. (2008). Lesson-Study Groups with Prospective and Practicing Teachers. Teaching Children Mathematics, 14(8), 472-478.

Rekalidou, G. (2012). Improving teaching. The case of Lesson Study. Pedagogy-Theory and Practice, 5, 98-109. http://www.pedagogy.gr/images/tefxoi/teuxos5.pdf

Rekalidou, G., Moumoulidou M., Karadimitriou, K., Mavrommatis, G., \& Salmont, E. (2013). Pilot implementation of the Lesson Study model in the Preschool Education Students Practicum Program. Practical training in initial teacher education: Research approaches. Ed: A. Androusou, \& S. Avgetidou. Practice Exercise Network, 
Department of Early Childhood Education. National and Kapodistrian University. Athens, 69-95.

Rekalidou, G., Karadimitriou, K., \& Moumoulidou M. (2014). Implementation of Lesson Study with students. Collaboration, reflection and feedback. Hellenic Journal of Research in Education, "Improving the Education of Future Teachers in Crisis of Institutions: Proposals, Applications". Alexandroupolis, May 2014, 7-28.

Saito, E., Hawe, P., Hadiprawiroc, S., \& Empedhe, S. (2008). Initiating education reform through lesson study at a university in Indonesia. Educational Action Research, 16(3), 391-406. https://doi.org/10.1080/09650790802260372

Saito, E. (2012). Key issues of lesson study in Japan and the United States: A literature review. Professional Development in Education, 38, 777-789. https://doi.org/10.1080/19415257.2012.668857

Sims, L., \& Walsh, D. (2009). Lesson Study with preservice teachers: Lessons from lessons. Teaching and Teacher Education, 25, 724-733. https://doi.org/10.1016/j.tate.2008.10.005

Stepanek, J., Appel, G., Leong, M., Turner Mangan, M., \& Mitchell, M. (2007). Leading Lesson Study. A practical guide for teachers and facilitators. California, USA.

Thompson, D. (2015). An Analysis of the Perceived Impact of Lesson Study on Improving Secondary School STEM Teacher Effectiveness. Electronic Theses and Dissertations. 1311. http://stars.library.ucf.edu/etd/1311

Wessels, H. (2018). Noticing in Pre-service Teacher Education: Research Lessons as a Context for Reflection on Learners' Mathematical Reasoning and Sense-Making. In: G. Kaiser et al. (eds.), Invited Lectures from the 13th International Congress on Mathematical Education. ICME-13 Monographs. https://doi.org/10.1007/978-3-319-72170-5_41 